\title{
US stock market regimes and oil price shocks
}

\author{
Timotheos Angelidis ${ }^{1}$, Stavros Degiannakis ${ }^{2}$, George Filis ${ }^{3,4} *$ \\ ${ }^{1}$ University of Peloponnese, Department of Economics, School of Management and \\ Economics, Tripolis Campus, 22100, Greece. \\ ${ }^{2}$ Department of Economics and Regional Development, Panteion University, \\ 136 Syngrou Avenue, GR17671, Athens, Greece. \\ ${ }^{3}$ Bournemouth University, Department of Accounting, Finance and Economics, \\ Executive Business Centre, 89 Holdenhurst Road, BH8 8EB, Bournemouth, UK. \\ ${ }^{4}$ Surrey Energy Economics Centre (SEEC), Faculty of Economics Business and Law, \\ University of Surrey, UK
}

*Corresponding author: email: gfilis@ bournemouth.ac.uk tel: 0044 (0) 01202968739, fax: 0044 (0) 01202968833

\begin{abstract}
The paper investigates the ability of oil price returns, oil price shocks and oil price volatility to provide predictive information on the state (high/low risk environment) of the US stock market returns and volatility. The disaggregation of oil price shocks according to their origin allows us to assess whether they contain incremental forecasting power compared to oil price returns. Overall, the results suggest that oil price returns and volatility possess the power to forecast the state of the US stock market returns and volatility. However, the full effects of oil price returns can only be revealed when the oil price shocks are disentangled and as such we claim that the oil price shocks have an incremental power in forecasting the state of the stock market. The findings are important for stock market forecasters and investors dealing with stock and derivatives markets.
\end{abstract}

Keywords: Oil price shocks, oil price volatility, regime switching, stock market volatility, US stock market.

JEL classification: C13, C32, C58, G10, Q40. 


\section{Introduction and review of the literature}

Since Hamilton's (1983) seminar paper there is a growing interest on the effects of oil prices on stock market returns, as well as, on the economy. The aim of this paper is to examine the relationship between the oil prices and the stock market from a different angle. In particular, we define a regime switching model specification and investigate whether oil price shocks and oil price volatility can predict the states of the stock market.

A large body of the academic literature has provided mounting empirical evidence regarding the relationship between oil prices and macroeconomic variables. In the main, the results suggest that oil prices exert a very significant impact on the economy either due to their effects on pricing and production costs or due to their effects on aggregate demand (i.e. via inflation and monetary policy channels) and aggregate supply (i.e. via the output). Some interesting studies on these views include those by Chen et al. (2014), Filis and Chatziantoniou (2014), Lippi and Nobili (2012), Baumeister and Peersman (2012), Segal (2011), Rahman and Serletis (2011), Tang et al. (2010), Nakov and Pescatori (2010), Jbir and Zouari-Ghorbel (2009), Blanchard and Gali (2007), Hamilton (2008, 1996), Hamilton and Herrera (2004), Barsky and Kilian (2004), Jones et al. (2004), Leduc and Sill (2004), Brown and Yucel (2002), Bernanke et al., (1997), Rotemberg and Woodford (1996), Huang et al. (1996), Mork et al. (1994), Mork (1989) and Burbidge and Harrison (1984).

Nevertheless, a strand in the literature over the last decade or so has been shaping around the concept that the relationship between oil prices and the economy has changed after the 80s (see, inter alia, Lescaroux and Mignon, 2008; Blanchard and Gali, 2007; Hooker, 2002, 1996; Bernanke et al., 1997; Darrat et al., 1996). Specifically, they maintain that oil price changes are not inflationary anymore and they do not significantly impact output levels and, thus, they do not constitute a source of recessionary periods.

Even though there is this extended literature on the relationship between oil prices and the macroeconomy, the research in the area of oil prices and stock markets is still growing. Portraying the readily available information, a negative relationship has been established between changes in oil prices and stock market returns (see, inter alia, Filis and Chatziantoniou, 2014; Asteriou and Bashmakova, 2013; Ciner, 2012; Lee and Chiou, 2011; Filis, 2010; Chen, 2010; Miller and Ratti, 2009; Driesprong et al., 2008; Nandha and Faff, 2008; O'Neill et al., 2008; Park and Ratti, 2008; 
Bachmeier, 2008; Henriques and Sadorsky, 2008; Sadorsky, 2001; Papapetrou, 2001; Ciner, 2001; Gjerde and Sættem, 1999; Huang et al., 1996; Jones and Kaul, 1996).

Contrary to the above, part of the literature finds that there is no relationship between oil price changes and stock market performance (see, inter alia, Jammazi and Aloui, 2010; Apergis and Miller, 2009; Cong et al., 2008).

Malik and Ewing (2009), Oberndorfer (2009) and Sadorsky (1999) further elucidate that apart from the oil prices, the oil price volatility impacts on stock returns, as well. They provide evidence that higher oil price volatility tends to cause a negative effect on stock market returns. Chiou and Lee (2009) also show that oil price volatility exerts a negative impact on the S\&P500 index.

Nevertheless, the aforementioned effects of oil stock market performance are far from definite. The status of the country as a net oil-importer or net oil-exporter provides additional information to these effects. Many authors subscribe to the belief that stock markets in oil-exporting countries tend to benefit from an oil price increase, whereas the reverse is true for the oil-importing countries (see, among others, Arouri and Rault, 2012; Mohanty et al., 2011; Korhonen and Ledyaeva, 2010; Bjornland, 2009; Lescaroux and Mignon, 2008 and Hammoudeh et al., 2004).

Furthermore, as suggested by Hamilton (2009a,b) and Kilian (2008a,b), not all oil price changes originate from the same source and, thus, they do not cause the same response from the financial markets. More specifically, the authors distinguish between supply-side and demand-side oil price shocks. Supply-side oil price shocks take place due to changes in the world oil supply, whereas demand-side oil price shocks are caused due to the increase in aggregate demand, arising mainly due to the industrialisation of developing countries like China (Hamilton 2009a,b). Kilian (2009) suggests that demand-side shocks could be further disentangled into aggregate demand shocks and oil specific demand shocks. The latter shock arises due to the uncertainty of the future availability of oil, whereas the former is the equivalent to Hamilton's demand-side shock. The general consensus from the literature regarding the oil price shocks and their impact is as follows: (a) supply-side shocks do not seem to exert any impact in the economy or the stock market. This is mainly due to the fact that disruptions in oil supply do not cause significant changes in oil prices, possibly because OPEC's decisions on oil supply levels are nowadays anticipated by the markets, (b) Demand-side shocks seem to trigger positive responses from the financial markets and the economy, whereas, (c) oil specific demand shocks, on the other hand, 
tend to exercise a negative effect. Some notable papers of authors who have considered the different origin of oil price shocks in their studies, are those by Degiannakis et al. (2014), Antonakakis and Filis (2013), Abhyankar et al. (2013), Degiannakis et al. (2013), Baumeister and Peersman (2012), Basher et al. (2012), Lippi and Nobili (2012), Kilian and Lewis (2011), Filis et al. (2011), Kilian and Park (2009), Apergis and Miller (2009), Lescaroux and Mignon (2008), Kilian (2008a) and Barsky and Kilian (2004).

Even though the oil literature is still growing, past findings do not provide evidence whether oil prices can predict the probability of a stock market to be bullish or bearish. Thus, adding to this literature, this study examines whether oil price shocks and oil price volatility can predict bullish stock market behaviour, using the state probabilities of a Markov-Switching model.

Some related studies to the aforementioned hypothesis include the papers by Chen (2010) and Aloui and Jammazi (2009). Aloui and Jammazi (2009) using a regime Markov-Switching EGARCH model were able to find evidence supporting the view that higher oil prices can explain higher stock market volatility and the transition from a stable regime to a volatile one. Similarly with Aloui and Jammazi (2009), Chen (2010) used a time varying transition probability Markov-Switching model to examine whether upward movements in the oil prices could lead stock markets to behave bearish. The results suggest that higher oil prices increase the probability of the stock market to move from a low variance regime to a high variance regime. Even more, the results show that higher oil prices force the stock market to remain in a high variance regime for a longer period of time.

This paper extends the work of Chen (2010) and Aloui and Jammazi (2009), following a different methodological approach, influenced by Chen (2009). Specifically, we do not assume that the transition probabilities are time-varying but we forecast the state of the stock market by using oil variables, as well as, a set of macroeconomic and financial indicators, which are used as control variables. This methodology gives us the ability to know in advance when and why a switch is expected to occur and not what affects the transition probabilities per se.

Overall, the contributions of this paper to the existing literature can be described succinctly. First, we disaggregate oil price shocks according to their origin; that is depending whether the oil price shock is coming from the supply side, the aggregate demand side or whether it is oil specific demand shock. The disaggregation 
enable us to examine which component affects the state of the stock market and hence to uncover hidden relations. Second, we examine whether the disaggregated oil price shocks contain incremental forecasting power on the state of the stock market in contrast to the oil prices.

In short, we show that oil price returns and volatility have the power to forecast the state of stock market returns and volatility. Nevertheless, we highlight that the full effects of oil price returns can only be revealed only if we disentangle the oil price shocks. Thus, we claim that the oil price shocks have an incremental power in forecasting the state of the stock market. Finally, a clear distinction is identified between the oil price shocks that affect the state probability of the stock market returns and those that affect the state probability of the stock market volatility.

The rest of the paper is organised as follows: Section 2 describes the dataset, while Section 3 decomposes the oil price shocks. Section 4 presents the econometric model employed and reports the empirical results. Section 5 provides evidence that the findings can be utilised by investors. Section 6 concludes the paper and discusses points for further research.

\section{Data description}

Monthly data from January, 1989 to December, 2011 from the US stock market are used. The Dow Jones index returns (RDOW), its dividend yield (DY), the US seasonally adjusted CPI (CPI), unemployment rate (UNEMP), interest rates (INT), as well as, the default spread (DS) are considered. The interest rates used in this study are the 3-month Treasury bill rates. The U.S. default spread is defined as the difference between Moody's seasoned Baa corporate bond yield and the ten-year Treasury constant maturity rate. Finally, the monthly stock market risk (VOLDOW) equals to:

$$
\operatorname{VOLDOW}=\sqrt{n_{t} \operatorname{Var}\left(r_{t, d}\right)}
$$

where $n_{t}$ is the number of days in month $t$ and $r_{t, d}$ is the daily return of Dow index in day $d$ of month $t$. We estimate similarly the monthly market risk for the oil prices (VOLOIL) ${ }^{1}$.

\footnotetext{
${ }^{1}$ There are two main frameworks for measuring current-looking volatility, i.e. realized and conditional volatility (see Degiannakis et al., 2014). The measure in equation (1) is based on the notion of realized volatility. The conditional volatility has also been considered and provides qualitatively similar results.
} 
Furthermore, we take into account monthly data for changes in oil production (OP), oil price returns (ROP) and real global economic activity (GEA), which are used to estimate the three oil price shocks (supply-side oil price shock, aggregate demand shocks and oil specific demand shock). More specifically, we collect data from Brent crude oil, which represents the $60 \%$ of the world oil daily consumption and, thus, it can be used as a proxy of the world oil prices (Maghyereh, 2004). We use oil production data, as a proxy for world oil supply. Finally, Kilian's (2009) measurement of the global economic activity is considered, which is based on dry cargo freight rates ${ }^{2}$.

The data for the Brent crude oil prices and oil production have been collected from the Energy Information Administration. Stock market prices, Dow Jones dividend yield, default spread, interest rates, CPI and unemployment are collected from Datastream ${ }^{\circledR}$. Stock market prices, oil prices and interest rates are expressed in real terms. Stock market returns, oil price changes, as well as, changes in oil production are estimated as the first log-difference. A visual representation of the variables can be seen in Figure 1.

\section{[FIGURE 1 HERE]}

In Figure 1 we observe the effects of the 2007 Great Recession which resulted in peaks for stock market and oil price volatilities, default spread and unemployment, as well as, troughs in stock and oil prices, CPI, interest rates and global economic activity. In addition, abrupt changes of oil prices, oil production and oil volatility can be also identified in the early 90s, which are associated with the first war in Iraq and the collapse of the Soviet Union.

\section{[TABLE 1 HERE]}

According to Table 1, the characteristics of the variables differ greatly. As expected, the financial variables along with the oil variables exhibit the highest volatility compared with the macroeconomic variables. Furthermore, the GEA is the only negative figure suggesting that the global economy was experiencing a contraction on average during the period of the study. In addition, notable information that we can extract from Table 1 is that both RDOW and INT have fluctuated into negative levels, as this is suggested by their minimum values. None of the variables

\footnotetext{
${ }^{2}$ The data can be found in Lutz Kilian personal website; http://www-personal.umich.edu/ lkilian/.
} 
are normally distributed as evident by the Jarque Bera test, as well as, the skewness and kurtosis measures.

[TABLE 2 HERE]

Table 2 reports the correlation matrix of the variables under consideration. We notice that the highest correlation is between DS and VOLDOW (positive). The latter figure is expected considering that the higher the default spread of a country the higher the uncertainty in the stock market. Some additional expected correlations are those among the RDOW, VOLDOW and DS. Regarding the oil variables, a negative coefficient exists between ROP and RDOW, as well as, between ROP and VOLDOW. Finally, VOLOIL is exhibiting a positive correlation with VOLDOW and a negative relationship with RDOW.

Overall, from this preliminary analysis we can observe that the oil price changes and oil price volatility have a negative relationship with the stock market performance, as it has also been suggested by the literature.

\section{Oil price shocks and historical decomposition}

As aforementioned, the aim of this paper is to examine whether the decomposition of oil price shocks according to their origin contain incremental forecasting power on the state of the stock market returns and volatility. Given that the literature has well document the incremental information of oil price shocks compared to oil price returns in stock market performance, we maintain that this could also hold for the different regimes of stock market returns and volatility.

We adopt Kilian's (2009) decomposition framework, which allows the identification of three oil price shocks (i.e. supply-side, aggregate demand and oil specific demand). A structural VAR model of order $p$ is applied:

$$
\boldsymbol{A}_{0} \boldsymbol{y}_{\mathrm{t}}=\boldsymbol{c}_{0}+\sum_{i=1}^{p} \boldsymbol{A}_{\mathrm{i}} \boldsymbol{y}_{\mathrm{t}-\mathrm{i}}+\boldsymbol{\varepsilon}_{\mathrm{t}}
$$

where, $\boldsymbol{y}_{\mathrm{t}}=\left[\begin{array}{lll}o p_{t} & g e a_{t} & r o p_{t}\end{array}\right]^{\prime}$ is a $3 \times 1$ vector of endogenous variables (changes in oil production, real global economic activity and oil price changes), $\boldsymbol{A}_{0}$ represents the $3 \times 3$ contemporaneous matrix, $\boldsymbol{A}_{\mathrm{i}}$ are $3 \times 3$ autoregressive coefficient matrices, $\boldsymbol{\varepsilon}_{\mathrm{t}}$ is the vector of structural disturbances, assumed to have zero covariance. The covariance matrix of the structural disturbances has the form $E\left[\boldsymbol{\varepsilon}_{\mathrm{t}} \boldsymbol{\varepsilon}_{t}^{\prime}\right]=\boldsymbol{D}=$ 
$\left[\begin{array}{ccc}\sigma_{1}^{2} & 0 & 0 \\ 0 & \sigma_{2}^{2} & 0 \\ 0 & 0 & \sigma_{3}^{2}\end{array}\right]$. In order to get the reduce form of the structural model, we multiply both sides with $\mathbf{A}_{0}^{-1}$, such as that:

$$
\boldsymbol{y}_{\mathrm{t}}=\boldsymbol{a}_{0}+\sum_{i=1}^{p} \boldsymbol{B}_{\mathrm{i}} \boldsymbol{y}_{\mathrm{t}-\mathrm{i}}+\boldsymbol{e}_{\mathrm{t}}
$$

where, $\boldsymbol{a}_{0}=\boldsymbol{A}_{0}^{-1} \boldsymbol{c}_{0}, \boldsymbol{B}_{\mathrm{i}}=\boldsymbol{A}_{0}^{-1} \boldsymbol{A}_{\mathrm{i}}$, and $\boldsymbol{e}_{\mathrm{t}}=\boldsymbol{A}_{0}^{-1} \boldsymbol{\varepsilon}_{\mathrm{t}}$. The reduced form errors $\mathbf{e}_{t}$ are linear combinations of the structural errors $\varepsilon_{t}$, with a covariance matrix of the form $E\left[\boldsymbol{e}_{\mathrm{t}} \boldsymbol{e}_{t}^{\prime}\right]=\boldsymbol{A}_{0}^{-1} \boldsymbol{D} \boldsymbol{A}_{0}^{-1^{\prime}}$.

The structural disturbances can be derived by imposing suitable restrictions on $\boldsymbol{A}_{0}$. The short-run restrictions that are applied in this model as the following:

$$
\left[\begin{array}{c}
\varepsilon_{1, t}^{S S} \\
\varepsilon_{2, t}^{A D S} \\
\varepsilon_{3, t}^{S D S}
\end{array}\right]=\left[\begin{array}{ccc}
a_{11} & 0 & 0 \\
a_{21} & a_{22} & 0 \\
a_{31} & a_{32} & a_{33}
\end{array}\right] \times\left[\begin{array}{c}
e_{1, t}^{o p} \\
e_{2, t}^{g e a} \\
e_{3, t}^{r o p}
\end{array}\right],
$$

where, $\mathrm{SS}=$ supply-side oil price shock, $\mathrm{ADS}=$ aggregate demand shock and SDS = oil specific demand shock.

The model restrictions are incorporated for the identification of the oil price shocks. Oil production is not responding contemporaneously to changes in oil demand due to the high adjustment costs. On the contrary, oil supply changes can contemporaneously influence global economic activity and the price of oil. Furthermore, the global economic activity is not contemporaneously influenced by oil prices, as it requires time for the world economy to react to oil price changes. Nevertheless, changes in the aggregate economic activity will have an immediate impact on oil prices due to the immediate reaction of the commodities markets. Finally, the oil price innovation could be triggered by supply-side events, aggregate demand-side events, as well as, oil specific demand events. Thus, oil production shocks, as well as, aggregate demand shocks can contemporaneously impact oil prices.

The historical decomposition of the oil price returns, according to the origin of the shock can be summarized in three steps (for more details please refer to Kilian and Park, 2009 and Burbidge and Harrison, 1985). First, the structural VAR model in eq.3 is estimated, which allows the identification of the three oil price shocks. Second, the estimated SVAR model is used to forecast the endogenous variables for periods $t+1, t+2, \ldots, t+s$. Finally, the forecast errors are decomposed into the cumulative 
contributions of the structural oil price shocks. For example, a $t+1$ vector of forecast errors, $\boldsymbol{e}_{\mathrm{t}+1}$, can be decomposed as $\boldsymbol{e}_{\mathrm{t}+1}=\sum_{i=1}^{3} \boldsymbol{e}_{t+1}^{(i)}$, where $i$ denotes the contribution of the $i^{\text {th }}$ structural shock to each element in the vector of forecast errors. We then use the cumulative effects of the supply-side (SS), aggregate demand (ADS) and oil specific demand shocks $(S D S)$ on oil price log-returns as predictive variables of the state of the US stock market returns and volatility.

\section{Oil price shocks and state of the stock market returns and volatility}

In this section, the incremental power of the oil price shocks and oil price volatility in forecasting the state of the stock market returns and volatility is investigated through a projection exercise. In order to achieve this goal, we, first, extract the states of the stock market by using a regime switching model. Then, the regimes of the stock market are predicted by using the lag values of the oil price shocks, oil volatility and a set of control variables.

\subsection{Regimes of stock market returns and volatility}

It is well documented (see for example Schaller and van Norden, 1997; Guidolin and Timmerman, 2005) that stock returns are characterised by at least two distinct regimes (bull and bear markets) ${ }^{3}$. We estimate a two-state regime switching model for the returns and the volatility of Dow Jones index and the model is written as:

$$
\begin{array}{cl}
y_{i, t}=\mu_{i, 1}+\varepsilon_{i, t, 1}, & \varepsilon_{i, t, 1} \sim \mathrm{N}\left(0, \sigma_{i, 1}^{2}\right) \\
y_{i, t}=\mu_{i, 2}+\varepsilon_{i, t, 2}, & \varepsilon_{i, t, 2} \sim \mathrm{N}\left(0, \sigma_{i, 2}^{2}\right),
\end{array}
$$

where $y_{i, t}$ is the variable of interest (return or volatility of Dow Jones for $i=1,2$, respectively), $\mu_{i, j}$ and $\sigma_{i, j}$ are the conditional mean and the standard deviation for state $j=1,2$. We assume that the return dispersion is a first order Markov, which is described by a binary variable $S_{t}=1,2$ and the constant probabilities $p, q$.

We calculate the regime classification measure that has been proposed by Ang and Bekaert (2002) to evaluate the quality of regime classification:

$$
R C M=400 \frac{1}{T} \sum_{t=1}^{T} p_{t}\left(1-p_{t}\right),
$$

\footnotetext{
${ }^{3}$ Even though the literature confirms the existence of two regimes, we let the data to provide us with the optimal number of regimes and we do not impose them a priori.
} 
where $p_{t}=\left(S_{t} \mid \mathcal{T}_{T}\right)$ and $\mathcal{T}_{T}$ is the information set for the entire sample. The $R C M$ statistic takes values between 0 and 100 with low values indicating good regime classification. For the return (volatility) index the measure equals to 26 (19) and, therefore, there are strong indications that the two-state regime switching model classifies correctly the periods of high and/or low risk.

Table 3 exhibits the estimated coefficients of the regime switching models, while Figure 2 plots the probability of state 1 (low risk environment) conditioned on all information in the sample based on Kim's (1994) algorithm. In the figure, the Dow Jones return and volatility are also plotted.

\section{[TABLE 3 HERE]}

\section{[FIGURE 2 HERE]}

The average monthly return during low volatility periods is statistically significant, while during periods of high risk the return is lower and statistically insignificant with standard deviation that is two times greater. The regimes are quite persistent as the probability to stay in the low (high) risk environment is equal to $98.36 \%(97.35 \%)$. The same picture emerges for the states of the volatility of Dow Jones returns. The annual volatility during high risk periods is 2.3 times greater than that of moderate periods while the volatility of volatility is almost 4 times greater. As expected, Figure 2 reveals that times of turbulence in market returns coincide with times of turbulence in risk (late 80s, 1998-2002, and 2008-2009).

\subsection{Projection exercise}

To explore the role of the variables of interest for the prediction of the future state of the Dow Jones returns and volatility, we estimate the following probit regression:

$$
P\left(\mathrm{~d}_{\mathrm{t}}=1\right)=\Phi\left(\beta_{i} \boldsymbol{O I L}_{t-1}, \gamma_{i} \operatorname{VOLOIL}_{t-1}, \boldsymbol{\delta}_{i} \boldsymbol{X}_{t-1}\right),
$$

where, $d_{t}=1$ when the state probability of stock market returns or volatility is greater than $50 \%{ }^{4}$, and $\mathrm{d}_{\mathrm{t}}=0$ otherwise and $\Phi$ is the cumulative distribution function of the standard normal distribution ${ }^{5}$. The explanatory variables include the $\boldsymbol{O I} \boldsymbol{L}_{\boldsymbol{t}}$

\footnotetext{
${ }^{4}$ For robustness purposes, we have estimated the same probit regression for $d_{t}=1$ when the state probability is greater than $80 \%$ and $90 \%$. Results are qualitatively similar and thus they are not report here.

5 A dynamic version of the probit model has been estimated, i.e. $P\left(\mathrm{~d}_{\mathrm{t}}=1\right)=\Phi\left(a_{i} d_{t-1}, \beta_{i} \boldsymbol{O} \boldsymbol{O I} \boldsymbol{L}_{t-1}, \gamma_{i}\right.$ VOLOIL $\left._{t-1}, \boldsymbol{\delta}_{i} \boldsymbol{X}_{t-1}\right)$, based on the fact that the state of stock market returns and volatility tend to be persistent. The results are qualitatively similar and available upon request.
} 
variable (either the oil price shocks $\left(S S_{t}, A D S_{t}, S D S_{t}\right)$ or the real oil price returns $\left(R O P_{t}\right)$ - depending on the model specification) and oil price volatility $\left(V O L O I L_{t}\right)$. We also include a vector $\boldsymbol{X}_{t}$, which includes the control variables that have been described in section $2 ; \boldsymbol{X}_{t}=\left[D S_{t}, I N T_{t}, C P I_{t}, D Y_{t}, U N E M P_{t}, D O W_{t}\right]^{\prime}$, where $D O W_{t}$ is the $R D O W_{t}\left(V O L D O W_{t}\right)$ on the returns (volatility) probit regression model. ${ }^{6}$

\subsubsection{Projection exercise: stock market returns regimes}

Table 4 presents the estimated coefficients of the probit regressions for the Dow Jones returns. Overall, the oil price volatility is negative and statistically significant on all specifications, suggesting that the higher the oil volatility the lower the probability of the stock market returns to be in state 1 . On the contrary, the real oil price returns do not seem to exercise a significant effect, as suggested by specifications 1 and 3 .

\section{[TABLE 4 HERE]}

Interestingly, when the real oil price returns are decomposed to the individual oil price shocks, the supply side and aggregate demand side shocks are exercising a significant effect (see specifications 4 and 5). The positive coefficients imply that these shocks are regarded as positive information by the market, suggesting that the stock market will be in a bullish state. Positive changes in these two shocks are affirmative information as (i) changes in the world oil production trigger lower oil prices and (ii) positive aggregate demand shocks, despite the fact that they tend to raise oil prices, originate from the increase in the global economic activity. These findings complement the conclusions of Basher et al. (2012), Lippi and Nobili (2012), Kilian and Lewis (2011), Filis et al. (2011) and Kilian and Park (2009). The control variables suggest that the default spread, real interest rates, CPI and dividend yield have a significant effect on the probability of the state on all specifications, although CPI is not significant in specification (2). In particular, the default spread, real interest rates and CPI exercise a negative effect suggesting that as their values increase the stock market tends to move away from the low risk environment. Furthermore, the dividend yield has a positive coefficient, which is once again expected.

\footnotetext{
${ }^{6}$ Similar methodology has been incorporated by Chen (2009), who showed that yield curve spreads and inflation rates predict bear markets. The order of the lags has been selected according to the information criteria, Akaike's Informaton Criterion and Schwarz's Bayesian Criterion.
} 
Based on Table 4, we maintain that unless we disentangle the oil price shocks, we cannot paint a complete picture on the predictive ability of oil prices on the state of the stock market. Thus, we argue the oil price shocks carry an incremental power in forecasting the state of the stock market returns compared to the real oil price changes variable.

\subsubsection{Projection exercise: stock market volatility regimes}

Subsequent, we examine the estimated coefficients of the probit regressions for the Dow Jones volatility, as these are presented in Table 5.

[TABLE 5 HERE]

The model specifications suggest that the effect of oil price volatility does not exercise a significant effect on Dow Jones volatility when all variables are taken into consideration (see specification 3 and 5). Nevertheless, the opposite result is observed for the oil prices. The Dow Jones volatility is negatively associated with real oil price returns, implying that increased oil prices tend to drive stock market volatility away from the low risk environment. Once again, though, unless we disentangle the origin of the oil price changes, we can only gain a partial inference, as demonstrated in specification 5. More specifically, focusing on the oil price shocks, we find that only the oil specific demand shock has the incremental power in forecasting the state of the stock market volatility. Thus, the effects of the oil price returns noted on specification 3 , is mainly determined by the oil specific demand shocks. This is an important finding, considering that the oil specific demand shocks have been characterised as uncertainty bearing shocks. Such claim stems from the fact that the events which cause oil specific demand shocks are related to political uncertainty, wars or changes in the inventory policies of the oil sector.

In terms of the control variables, the evidence reveals that all variables are significant with the expected signs. In particular, we report that default spreads, interest rates and unemployment tend to decrease the probability of volatility to remain in the low risk environment, whereas the reverse hold true for the remaining control variables.

Overall, the results provide evidence that oil price returns and volatility possess the power to forecast the state of stock market returns and volatility, as changes in these variables cause stock market returns and volatility to switch to a different state. Nevertheless, we show that the full effects of oil price returns can only 
be revealed when the oil price shocks are isolated and as such we claim that the oil price shocks have an incremental power in forecasting the state of the stock market. An interesting finding is that there is a clear distinction between the oil price shocks that affect the state probability of the stock market returns (i.e. only the supply-side and aggregate demand shocks) and the state probability of the stock market volatility (i.e. only the oil specific demand shock). Overall, the findings on both stock market returns and volatility complement the studies that have documented the incremental information that can be obtained by the oil price shocks compared to the oil price returns (see, for instance, Degiannakis et al., 2014; Antonakakis and Filis, 2013; Abhyankar et al., 2013; Degiannakis et al., 2013; Baumeister and Peersman, 2012; Basher et al., 2012; Lippi and Nobili, 2012; Kilian and Lewis, 2011; Filis et al., 2011; Kilian and Park,2009; Apergis and Miller, 2009; Lescaroux and Mignon; 2008; Kilian, 2008a; and Barsky and Kilian, 2004).

\section{Portfolio performance based on the predicted market regimes}

This section provides solid evidence in favour of the use of oil shocks and oil price volatility to predict the stock market regimes by examining portfolio performance. We compare two traders that adjust their portfolios according to their information for the state of the market. The first trader uses the predicted market regimes based on equation (4) to adjust her portfolio, whereas the second trader is using the forecasted market regimes based on the forecast of the state of the market from the probit regression (equation 6). The traders assume a long position when the market is in the low risk environment while a short position is followed when the market is in the high risk environment. Portfolio returns are computed as the cumulative log-returns for the investment horizon which coincides with the period over study.

Table 6 summarises the cumulative returns for both traders for the Dow Jones index, as well as, its volatility, whereas Figure 3 exhibits the line graph of the cumulative returns. It is evident that in both cases the trader who is using the forecasted market regimes based on oil price shocks and oil price volatility enjoys higher portfolio returns. This is particularly apparent on the volatility portfolio. The volatility trading strategy has been replicated using the Dow Jones implied volatility 
index (VXD) instead of VOLDOW and the results are qualitatively similar ${ }^{7}$. The VXD index has launched in October, 1997, thus the investment period is shorter: October, 1997-December, 2011. Overall, this example verifies the importance of using oil price shocks and volatility to forecast market regimes and make portfolio adjustments accordingly.

\section{[TABLE 6 HERE] \\ [FIGURE 3 HERE]}

\section{Conclusion}

The study investigates whether oil price shocks and oil price volatility can predict the stock market low risk state, as this is approximated by positive returns and low volatility, using a regime switching model. To identify the oil price shocks we follow a similar methodology with Kilian and Park (2009).

The paper extends the work by Chen (2010) and Aloui and Jammazi (2009), although a different methodological approach is followed, based on Chen (2009). Specifically, we do not assume time-varying transition probabilities, but we forecast the state of the stock market by using oil variables and a set of macroeconomic and financial indicators, which serve as control variables.

The contributions of the paper are: (i) We disaggregate oil price shocks, which enables us to examine the components that affect the state of the stock market and, hence, we are able to reveal hidden relations. (ii) We examine whether the decomposed oil price shocks contain incremental forecasting power on the state of the stock market compared to the oil price returns.

The regime switch results allow us to detect two episodes of stock market behaviour. The low risk environment is related to high returns and low volatility, whereas the reverse holds for the high risk environment.

The findings from the probit regressions suggest that oil price shocks and volatility have the incremental power in forecasting the state of the US stock market returns and volatility. In addition, we show that there is a clear distinction between the oil price shocks that affect the state probability of the stock market returns and those

\footnotetext{
${ }^{7}$ The VXD, or CBOE DJIA Volatility Index, is based on real-time prices of options on the Dow Jones Industrial Average. The VXD index reflects investors' consensus view of future (30 calendar days) expected stock market volatility. The VOLDOW is the estimate of the volatility; hence, its actual replication in a portfolio is not a straightforward task. However, the volatility trading strategy is directly applied with the VXD, as the CBOE Futures Exchange has introduced futures on the VXD Index (the CBOE DJIA Volatility Index Futures).
} 
that affect the state probability of the stock market volatility. These findings are important to investors who want to predict the state of the market and adjust accordingly the weights of the assets they hold, i.e. switch to low risk investment (cash) when it is anticipated a high risk state. In addition, these results can be utilised by investors who trade options as the volatility is the key component of option prices.

An interesting question that future study could examine is whether oil price shocks have incremental forecasting ability on the state of other financial variables (such as the Amihud's illiquidity) or economic variables (such as, interest rate, bond returns, term spread, default spread). Finally, another avenue for further research would be the examination of the forecasting ability of oil price shocks on the state of industrial sectors returns and volatility, as well as, on both net-oil importing and net oil-exporting countries.

\section{Acknowledgements}

We thank the editor Prof. Manuchehr Shahrokhi, the anonymous referees and Prof. Robin Lumsdaine for their constructive comments and suggestions which helped us to improve the scope and clarity of the paper. We also thank the participants of the $21 \mathrm{st}$ Annual Conference of the Multinational Finance Society for the valuable comments.

The views expressed are those of the authors and should not be interpreted as those of their respective institutions. The authors are solely responsible for any remaining errors and deficiencies.

\section{References}

Abhyankar, A., B. Xu and J. Wang (2013). Oil price shocks and the stock market: Evidence from Japan. Energy Journal, 34, 199-222.

Aloui, C. and R. Jammazi (2009). The effects of crude oil shocks on stock market shifts behaviour: a regime switching approach. Energy Economics, 31, 789-799.

Ang, A. and G. Bekaert (2002). Regime switches in interest rates. Journal of Business and Economic Statistics, 20, 163-182.

Antonakakis, N. and G. Filis (2013). Oil prices and stock market correlation: A timevarying approach. International Journal of Energy and Statistics, 1, 17-29.

Apergis, N. and S.M. Miller (2009). Do structural oil-market shocks affect stock prices? Energy Economics, 31, 569-575. 
Arouri, M.E.H. and C. Rault (2012). Oil prices and stock markets in GCC countries: Empirical evidence from panel analysis. International Journal of Finance and Economics, 17, 242-253.

Asteriou, D. and Y. Bashmakova (2013). Assessing the impact of oil returns on emerging stock markets: A panel data approach for ten Central and Eastern European Countries. Energy Economics, 38, 204-211.

Bachmeier, L. (2008). Monetary policy and the transmission of oil shocks. Journal of Macroeconomics, 30, 1738-1755.

Barsky, R. and L. Kilian (2004). Oil and the macroeconomy since the 1970s. Journal of Economic Perspectives, 18, 115-134.

Basher, S.A., A.A. Haug, and P. Sadorsky (2012). Oil prices, exchange rates and emerging stock markets. Energy Economics, 34, 227-240.

Baumeister, C. and G. Peersman (2012). Time-varying effects of oil supply shocks on the US economy. Bank of Canada Working Paper Series, WP2012-02.

Bernanke, S.B., M. Gertler, and M. Watson (1997). Systematic monetary policy and the effects of oil price shocks. Brookings Papers on Economic Activity, 1, 91-148.

Bjornland, H.C. (2009). Oil price shocks and stock market booms in an oil exporting country. Scottish Journal of Political Economy, 56, 232-254.

Blanchard, J.O. and J. Gali (2007). The macroeconomic effects of oil price shocks. Why are the 2000s so different than the 1970s? National Bureau of Economic Research, Working Paper, 13368.

Brown, P.A.S. and M.K. Yücel (2002). Energy prices and aggregate economic activity: an interpretative survey. The Quarterly Review of Economics and Finance, 42, 193-208.

Burbidge, J. and A. Harrison (1984). Testing for the effects of oil-price rises using vector autoregressions. International Economic Review, 25, 459-484

Burbidge, J. and A. Harrison (1985). A historical decomposition of the Great Depression to determine the role of money. Journal of Monetary Economics, 16, 45-54.

Chen, S.-S. (2009). Predicting the bear stock market: Macroeconomic variables as leading indicators. Journal of Banking and Finance, 33, 211-223.

Chen, S.-S. (2010). Do higher oil prices push the stock market into bear territory? Energy Economics, 32, 490-495. 
Chen, W., S. Hamori and T. Kinkyo (2014). Macroeconomic impacts of oil prices and underlying financial shocks. Journal of International Financial Markets, Institutions and Money, 29, 1-12.

Chiou, J.-S. and Y.-H. Lee (2009). Jump dynamics and volatility: Oil and the stock markets. Energy, 34, 788-796.

Ciner, C. (2001). Energy shocks and financial markets: nonlinear linkages. Studies in Nonlinear Dynamics \& Econometrics, 5, 203-212.

Ciner, C. (2012). Oil and stock returns: Frequency domain evidence. Journal of International Financial Markets, Institutions and Money, 23, 1-11.

Cong, R.-G., Y.-M. Wei, J.-L. Jiao, and Y. Fan (2008). Relationships between oil price shocks and stock market: An empirical analysis from China. Energy Policy, 36, 3544-3553.

Darrat, A.F., O.W. Gilley, and D.J. Meyer (1996). US oil consumption, oil prices, and the macroeconomy. Empirical Economics, 21, 317-334.

Degiannakis, S., G. Filis and C. Floros (2013). Oil and stock returns: Evidence from European industrial sector indices in a time-varying environment. Journal of International Financial Markets, Institutions and Money, 26, 175-191.

Degiannakis, S., G. Filis, and R. Kizys (2014). The Effects of Oil Price Shocks on Stock Market Volatility: Evidence from European Data. Energy Journal, forthcoming.

Driesprong, G., B. Jacobsen, and B. Maat (2008). Striking oil: Another puzzle? Journal of Financial Economics, 89, 307-327.

Filis, G. (2010). Macro economy, stock market and oil prices: Do meaningful relationships exist among their cyclical fluctuations? Energy Economics, 32, 877886.

Filis, G. and I. Chatziantoniou (2014). Financial and monetary policy responses to oil price shocks: evidence from oil-importing and oil-exporting countries. Review of Quantitative Finance and Accounting, forthcoming.

Filis, G., S. Degiannakis, and C. Floros (2011). Dynamic correlation between stock market and oil prices: The case of oil-importing and oil-exporting countries. International Review of Financial Analysis, 20, 152-164.

Gjerde, Ø. and F. Sættem (1999). Causal relations among stock returns and macroeconomic variables in a small, open economy. Journal of International Financial Markets, Institutions and Money, 9, 61-74. 
Guidolin, M. and A. Timmerman (2005). Economic implications of bull and bear regimes in UK stock and bond returns. Economic Journal, 115, 111-143.

Hamilton, J.D. (1983). Oil and the macroeconomy since World War II. Journal of Political Economy, 91, 228-248.

Hamilton, J.D. (1996). This is what happened to the oil price-macroeconomy relationship. Journal of Monetary Economics, 38, 215-220.

Hamilton, J.D. (2008). Oil and the macroeconomy. New Palgrave Dictionary of Economics, $2^{\text {nd }}$ edition, edited by Durlauf, S. and Blume, L., Palgrave McMillan Ltd.

Hamilton, J.D. (2009a). Understanding crude oil prices. Energy Journal, 30, 179-206.

Hamilton, J.D. (2009b). Causes and consequences of the oil shock of 2007-08. Brookings Papers on Economic Activity, Spring, 215-261.

Hamilton, J.D. and A.M. Herrera (2004). Oil shocks and aggregate macroeconomic behavior: The role of monetary policy. Journal of Money, Credit, and Banking, $36,265-286$.

Hammoudeh, S., S. Dibooglu and E. Aleisa (2004). Relationships among U.S. Oil prices and oil industry equity indices. International Review of Economics and Finance, 13, 427-453.

Henriques, I. and Sadorsky, P. (2008). Oil price and the stock prices of alternative energy companies. Energy Economics, 30, 998-1010.

Hooker, A.M. (1996). What happened to the oil price-macroeconomy relationship? Journal of Monetary Economics, 38, 195-213.

Hooker, A.M. (2002). Are oil shocks inflationary? Asymmetric and nonlinear specifications versus changes in regime. Journal of Money, Credit and Banking, 34, 540-561.

Huang, R.D., R.W. Masulis, and H.R. Stoll (1996). Energy shocks and financial markets. Journal of Futures Markets, 16, 1-27.

Huber, P.J. (1967). The behavior of maximum likelihood estimates under nonstandard conditions. Proceedings of the Fifth Berkeley Symposium on Mathematical Statistics and Probability, 221-233.

Jammazi, R. and C. Aloui (2010). Wavelet decomposition and regime shifts: Assessing the effects of crude oil shocks on stock market returns. Energy Policy, $38,1415-1435$. 
Jbir, R. and S. Zouari-Ghorbel (2009). Recent oil price shock and Tunisian economy. Energy Policy, 37, 1041-1051.

Jones, M.C. and G. Kaul (1996). Oil and the stock markets. Journal of Finance, 51, 463-491.

Jones, D.W., P.N., Lelby and I.K. Paik (2004). Oil prices shocks and the macroeconomy: What has been learned since. Energy Journal, 25, 1-32.

Kilian, L. (2008a). Exogenous oil supply shocks: how big are they and how much do they matter for the US economy? Review of Economics and Statistics, 90, 216240.

Kilian, L. (2008b). The economic effects of energy price shocks. Journal of Economic Literature, 46, 871-909.

Kilian, L. (2009). Not all oil price shocks are alike: Disentangling demand and supply shocks in the crude oil market. American Economic Review, 99, 1053-1069.

Kilian, L. and C. Park (2009). The impact of oil price shocks on the U.S. stock market. International Economic Review, 50, 1267-1287.

Kilian, L. and L.T. Lewis (2011). Does the Fed respond to oil price shocks? The Economic Journal, 121, 1047-1072.

Kim, C.-J. (1994). Dynamic linear models with Markov Switching. Journal of Econometrics, 60, 1-22.

Korhonen, I. and S. Ledyaeva (2010). Trade linkages and macroeconomic effects of the price of oil. Energy Economics, 32, 848-856.

Leduc, S. and K. Sill (2004). A quantitative analysis of oil-price shocks, systematic monetary policy and economic downturns. Journal of Monetary Economics, 51, 781-808.

Lee, Y-H. and J-S Chiou (2011). Oil sensitivity and its asymmetric impact on the stock market. Energy, 36, 168-174.

Lescaroux, F. and V. Mignon (2008). On the influence of oil prices on economic activity and other macroeconomic and financial variables. OPEC Energy Review, 32, 343-380.

Lippi, F. and A. Nobili (2012). Oil and the macroeconomy: A quantitative structural analysis. Journal of the European Economic Association, 10, 1059-1083.

Maghyereh, A. (2004). Oil price shocks and emerging stock markets. A generalized VAR approach. International Journal of Applied Econometrics and Quantitative Studies, 1, 27-40. 
Malik, F. and B.T. Ewing (2009). Volatility transmission between oil prices and equity sector returns. International Review of Financial Analysis, 18, 95-100.

Miller, J.I. and R.A. Ratti (2009). Crude oil and stock markets: Stability, instability, and bubbles. Energy Economics, 31, 559-568.

Mohanty, S.K., M., Nandha, A.Q., Turkistani and M.Y. Alaitani (2011). Oil price movements and stock market returns: Evidence from Gulf Cooperation Council (GCC) countries. Global Finance Journal, 22, 42-55.

Mork, K.A. (1989). Oil and the macroeconomy when prices go up and down: An extension of Hamilton's results. Journal of Political Economy, 91, 740-744.

Mork, K.A., O. Olsen and H.T. Mysen (1994). Macroeconomic responses to oil price increases and decreases in seven OECD countries. The Energy Journal, 15, 1935 .

Nakov, A. and A. Pescatori (2010). Oil and the great moderation. Economic Journal, $120,131-156$

Nandha, M. and R. Faff (2008). Does oil move equity prices? A global view. Energy Economics, 30, 986-997.

Oberndorfer, U. (2009). Energy prices, volatility, and the stock market: Evidence from the Eurozone. Energy Policy, 37, 5787-5795.

O'Neill, J.T., J. Penm, and D.R. Terrell (2008). The role of higher oil prices: A case of major developed countries. Research in Finance, 24, 287-299.

Papapetrou, E. (2001). Oil price shocks, stock market, economic activity and employment in Greece. Energy Economics, 23, 511-532.

Park, J. and R.A. Ratti (2008). Oil prices and stock markets in the U.S. and 13 European countries. Energy Economics, 30, 2587-2608.

Rahman, S. and A. Serletis (2011). The asymmetric effects of oil price shocks. Macroeconomic Dynamics, 15, 437-471.

Rotemberg, J. J. and M. Woodford (1996). Imperfect competition and the effects of energy price increases on economic activity. Journal of Money, Credit and Banking, 28, 549-77.

Sadorsky, P. (1999). Oil price shocks and stock market activity. Energy Economics, 21, 449-469.

Sadorsky, P. (2001). Risk factors in stock returns of Canadian oil and gas companies. Energy Economics, 23, 17-28. 
Schaller, H. and S. van Norden (1997). Regime switching in stock market returns. Applied Financial Economics, 7, 177-191.

Segal, P. (2011). Oil price shocks and the macroeconomy. Oxford Review of Economic Policy, 27, 169-185.

Tang, W., L. Wu and Z.X. Zhang (2010). Oil price shocks and their short and longterm effects on the Chinese economy. Energy Economics, 32, S3-S14.

White, H. (1980). A Heteroskedasticity-consistent covariance matrix estimator and a direct test for heteroskedasticity. Econometrica, 48, 817-838. 


\section{Tables}

\begin{tabular}{|c|c|c|c|c|c|c|c|c|c|c|c|}
\hline & $\begin{array}{c}\text { Dow } \\
\text { Jones } \\
\text { Returns }\end{array}$ & $\begin{array}{c}\text { Dow Jones } \\
\text { Realised } \\
\text { Volatility }\end{array}$ & $\begin{array}{l}\text { Div. } \\
\text { Yield }\end{array}$ & Inflation & $\begin{array}{c}\text { Interest } \\
\text { Rates }\end{array}$ & Un/ment & $\begin{array}{l}\text { Default } \\
\text { Spread }\end{array}$ & $\begin{array}{c}\text { Oil } \\
\text { Price } \\
\text { Returns }\end{array}$ & $\begin{array}{c}\text { Oil } \\
\text { Pr/tion }\end{array}$ & $\begin{array}{c}\text { Global } \\
\text { Ec. } \\
\text { Activity }\end{array}$ & $\begin{array}{c}\text { Oil } \\
\text { Price } \\
\text { Vol/ty }\end{array}$ \\
\hline Mean & 0.003 & 0.157 & 0.020 & 0.028 & 0.009 & 0.059 & 0.022 & 0.005 & 0.001 & -0.004 & 0.333 \\
\hline Median & 0.010 & 0.135 & 0.018 & 0.028 & 0.010 & 0.055 & 0.020 & 0.021 & 0.001 & -0.039 & 0.307 \\
\hline Maximum & 0.110 & 0.789 & 0.039 & 0.064 & 0.044 & 0.100 & 0.061 & 0.444 & 0.044 & 0.550 & 1.467 \\
\hline Minimum & -0.186 & 0.044 & 0.009 & -0.020 & -0.041 & 0.380 & 0.012 & -0.502 & -0.060 & -0.506 & 0.112 \\
\hline Std. Dev. & 0.045 & 0.098 & 0.006 & 0.013 & 0.020 & 0.015 & 0.008 & 0.109 & 0.010 & 0.228 & 0.156 \\
\hline Skewness & -0.771 & 2.646 & 0.671 & -0.274 & -0.489 & 1.092 & 1.902 & -0.621 & -0.976 & 0.451 & 2.650 \\
\hline Kurtosis & 4.396 & 13.560 & 2.568 & 4.504 & 2.404 & 3.343 & 8.083 & 5.280 & 9.880 & 2.662 & 15.144 \\
\hline Jarque-Bera & 49.7 & 1604.5 & 22.8 & 29.4 & 15.1 & 56.1 & 463.6 & 77.5 & 588.1 & 10.6 & 2019.0 \\
\hline Probability & 0.000 & 0.000 & 0.000 & 0.000 & 0.001 & 0.000 & 0.000 & 0.000 & 0.000 & 0.005 & 0.000 \\
\hline
\end{tabular}


Table 2. Correlation coefficients of the variables under investigation. The sample period runs from January 1989 to December, 2011.

\begin{tabular}{|c|c|c|c|c|c|c|c|c|c|c|c|}
\hline & $\begin{array}{c}\text { Dow } \\
\text { Jones } \\
\text { Returns } \\
\end{array}$ & $\begin{array}{c}\text { Dow } \\
\text { Jones } \\
\text { Realised } \\
\text { Volatility }\end{array}$ & $\begin{array}{l}\text { Div. } \\
\text { Yield }\end{array}$ & Inflation & $\begin{array}{c}\text { Interest } \\
\text { Rates }\end{array}$ & Un/ment & $\begin{array}{l}\text { Default } \\
\text { Spread }\end{array}$ & $\begin{array}{c}\text { Oil } \\
\text { Price } \\
\text { Returns }\end{array}$ & $\begin{array}{c}\text { Oil } \\
\text { Pr/tion } \\
\end{array}$ & $\begin{array}{c}\text { Global } \\
\text { Ec. } \\
\text { Activity }\end{array}$ & $\begin{array}{c}\text { Oil Price } \\
\text { Vol/ty }\end{array}$ \\
\hline Dow Jones Returns & 1.000 & & & & & & & & & & \\
\hline $\begin{array}{c}\text { Dow Jones Realised } \\
\text { Volatility }\end{array}$ & -0.366 & 1.000 & & & & & & & & & \\
\hline Dividend Yield & -0.044 & -0.135 & 1.000 & & & & & & & & \\
\hline Inflation & -0.124 & -0.197 & 0.433 & 1.000 & & & & & & & \\
\hline Interest Rates & 0.148 & -0.275 & 0.108 & -0.027 & 1.000 & & & & & & \\
\hline Unemployment & 0.047 & 0.100 & 0.338 & -0.285 & -0.544 & 1.000 & & & & & \\
\hline Default Spread & -0.160 & 0.762 & -0.111 & -0.381 & -0.512 & 0.394 & 1.000 & & & & \\
\hline Oil Price Returns & -0.087 & -0.139 & -0.045 & -0.041 & 0.025 & -0.003 & -0.088 & 1.000 & & & \\
\hline Oil Production & 0.021 & -0.005 & -0.040 & -0.012 & -0.030 & 0.014 & 0.002 & -0.076 & 1.000 & & \\
\hline $\begin{array}{c}\text { Global Economic } \\
\text { Activity }\end{array}$ & 0.039 & -0.130 & -0.046 & 0.157 & -0.349 & 0.047 & -0.056 & 0.069 & 0.052 & 1.000 & \\
\hline Oil Price Volatility & -0.088 & 0.402 & -0.001 & 0.016 & 0.006 & -0.112 & 0.317 & -0.091 & -0.148 & -0.189 & 1.000 \\
\hline
\end{tabular}


Table 3. The estimated coefficients of the regime switching model.

The model is $y_{i, t}=\mu_{i, j}+\varepsilon_{i, t, j}, \quad \varepsilon_{i, t, j} \sim \mathrm{N}\left(0, \sigma_{i, j}^{2}\right)$, where $y_{i, t}$ is the variable of interest (return or volatility of Dow Jones for $i=1,2$, respectively), $\mu_{i, j}$ and $\sigma_{i, j}$ are the conditional mean and the standard deviation for state $j=1,2$. The sample period runs from January, 1989 to December, 2011.

\begin{tabular}{cccccccc}
\hline & $\mu_{1}$ & $\mu_{2}$ & $\sigma_{1}$ & $\sigma_{2}$ & $p$ & $q$ & $R C M$ \\
\hline Dow Jones Returns & $0.008^{* * *}$ & 0.0005 & $0.025^{* * *}$ & $0.054^{* * *}$ & $98.36 \% * * *$ & $97.35 \% * * *$ & 26.4 \\
$\left(\mathrm{y}_{1, \mathrm{t}}\right)$ & $(0.0027)$ & $(0.0047)$ & $(0.0021)$ & $(0.0032)$ & $(0.0154)$ & $(0.0217)$ & \\
\hline Dow Jones Realised & $0.105^{* * *}$ & $0.231^{* * *}$ & $0.030^{* * *}$ & $0.111^{* * *}$ & $96.13 \% * * *$ & $95.30 \% \%^{* * *}$ & 19.8 \\
volatility $\left(\mathrm{y}_{2, \mathrm{t}}\right)$ & $(0.0025)$ & $(0.0179)$ & $(0.0021)$ & $(0.0057)$ & $(0.0162)$ & $(0.0248)$ & \\
\hline
\end{tabular}

*** denote statistical significance at the $1 \%$ level. Standard errors are reported in brackets.

Note: $p, q$ are constant probabilities of remaining in regime 1 or 2, respectively. RCM is the regime classification measure proposed by Ang and Bekaert (2002) to evaluate the quality of regime classification. 
Table 4. Probit regression results: $P\left(\mathrm{~d}_{\mathrm{t}}=1\right)=\Phi\left(\beta_{i} \boldsymbol{O I L}_{t-1}, \gamma_{i}\right.$ VOLOIL $\left._{t-1}, \boldsymbol{\delta}_{i} \boldsymbol{X}_{t-1}\right)$ where, $\mathrm{d}_{\mathrm{t}}=1$ when the state probability for the Dow Jones returns is greater than $50 \%$, and $\mathrm{d}_{\mathrm{t}}=2$ otherwise. $\Phi$ is

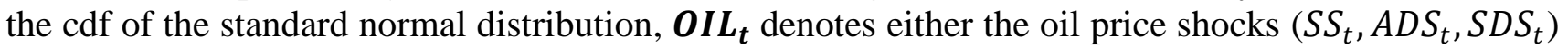
or the real oil price returns $\left(R O P_{t}\right), V O L O I L_{t}$ is the oil price volatility, and $\boldsymbol{X}_{t}$ includes the control variables $D S_{t}, I N T_{t}, C P I_{t}, D Y_{t}, U N E M P_{t}, R D O W_{t}$. The sample period runs from January, 1989 to December, 2011.

\begin{tabular}{|c|c|c|c|c|c|c|c|c|c|c|}
\hline $\begin{array}{l}\text { Independent } \\
\text { Variables: }\end{array}$ & $(1)$ & & (2) & & (3) & & (4) & & (5) & \\
\hline Constant & $\begin{array}{r}0.9911 \\
(0.2872)\end{array}$ & $* * *$ & $\begin{array}{l}10.0343 \\
(1.0242)\end{array}$ & $* * *$ & $\begin{array}{l}11.6304 \\
(1.2695)\end{array}$ & $* * *$ & $\begin{array}{r}0.9777 \\
(0.2933)\end{array}$ & $* * *$ & $\begin{array}{l}12.5420 \\
(1.4341)\end{array}$ & $* * *$ \\
\hline Supply Side Shock $_{t-1}$ & & & & & & & $\begin{array}{r}5.2151 \\
(4.3846)\end{array}$ & & $\begin{array}{l}15.3078 \\
(6.1956)\end{array}$ & $* *$ \\
\hline $\begin{array}{l}\text { Aggregate Demand } \\
\text { Shock }_{t-1}\end{array}$ & & & & & & & $\begin{array}{r}7.1377 \\
(3.6001)\end{array}$ & $* *$ & $\begin{array}{r}14.0791 \\
(5.2716)\end{array}$ & $* * *$ \\
\hline $\begin{array}{l}\text { Oil Specific Demand } \\
\text { Shock }_{t-1}\end{array}$ & & & & & & & $\begin{array}{r}-0.6270 \\
(0.7984)\end{array}$ & & $\begin{array}{l}-0.7019 \\
(1.2262)\end{array}$ & \\
\hline Oil Price Returns $s_{t-1}$ & $\begin{array}{r}-0.3347 \\
(0.7709)\end{array}$ & & & & $\begin{array}{r}-0.3511 \\
(1.2145)\end{array}$ & & & & & \\
\hline Oil Price Volatility $_{t-1}$ & $\begin{array}{l}-3.9458 \\
(0.9132)\end{array}$ & $* * *$ & & & $\begin{array}{r}-3.7873 \\
(1.2045)\end{array}$ & $* * *$ & $\begin{array}{r}-4.0920 \\
(0.9439)\end{array}$ & $* * *$ & $\begin{array}{r}-4.1368 \\
(1.2352)\end{array}$ & $* * *$ \\
\hline Default Spread $_{t-1}$ & & & $\begin{array}{r}-4.0663 \\
(0.3921)\end{array}$ & $* * *$ & $\begin{array}{r}-4.1420 \\
(0.4063)\end{array}$ & $* * *$ & & & $\begin{array}{r}-4.4475 \\
(0.4661)\end{array}$ & $* * *$ \\
\hline Interest Rates $_{t-1}$ & & & $\begin{array}{l}-90.5936 \\
(9.8405)\end{array}$ & $* * *$ & $\begin{array}{l}-90.9008 \\
(9.9403)\end{array}$ & $* * *$ & & & $\begin{array}{r}-97.1331 \\
(11.7862)\end{array}$ & $* * *$ \\
\hline Inflation $_{t-1}$ & & & $\begin{array}{l}-20.0316 \\
(14.5105)\end{array}$ & & $\begin{array}{r}-37.5639 \\
(18.9521)\end{array}$ & $* *$ & & & $\begin{array}{r}-44.6543 \\
(19.6781)\end{array}$ & $* *$ \\
\hline Dividend Yield It- $_{1}$ & & & $\begin{array}{r}56.4481 \\
(17.7016)\end{array}$ & $* * *$ & $\begin{array}{r}36.7082 \\
(19.7332)\end{array}$ & $*$ & & & $\begin{array}{r}48.2223 \\
(20.6517)\end{array}$ & $* *$ \\
\hline Unemployment $_{t-1}$ & & & $\begin{array}{r}0.4284 \\
(4.5086)\end{array}$ & & $\begin{array}{r}2.4084 \\
(4.7094)\end{array}$ & & & & $\begin{array}{r}0.5216 \\
(4.7497)\end{array}$ & \\
\hline Dow Jones Returns $s_{t-1}$ & & & $\begin{array}{r}0.2241 \\
(2.8812)\end{array}$ & & $\begin{array}{r}-0.5937 \\
(3.2761)\end{array}$ & & & & $\begin{array}{r}0.2261 \\
(3.5041)\end{array}$ & \\
\hline McFadden $R^{2}$ & 0.0911 & & 0.4965 & & 0.5231 & & 0.1065 & & 0.5567 & \\
\hline
\end{tabular}


Table 5. Probit regression results: $P\left(\mathrm{~d}_{\mathrm{t}}=1\right)=\Phi\left(\beta_{i} \boldsymbol{O I L}_{t-1}, \gamma_{i} V O L O I L_{t-1}, \boldsymbol{\delta}_{i} \boldsymbol{X}_{t-1}\right)$ where, $\mathrm{d}_{\mathrm{t}}=1$ when the state probability for the Dow Jones volatility is greater than $50 \%$, and $\mathrm{d}_{\mathrm{t}}=2$ otherwise. $\Phi$ is the cdf of the standard normal distribution, $\mathbf{O I} \boldsymbol{L}_{\boldsymbol{t}}$ denotes either the oil price shocks $\left(S S_{t}, A D S_{t}, S D S_{t}\right)$ or the real oil price returns $\left(R O P_{t}\right), V O L O I L_{t}$ is the oil price volatility, and $\boldsymbol{X}_{t}$ includes the control variables $D S_{t}, I N T_{t}, C P I_{t}, D Y_{t}, U N E M P_{t}, V O L D O W_{t}$. The sample period runs from January, 1989 to December, 2011.

\begin{tabular}{|c|c|c|c|c|c|c|c|c|c|c|}
\hline $\begin{array}{l}\text { Independent } \\
\text { Variables: }\end{array}$ & (1) & & (2) & & (3) & & (4) & & (5) & \\
\hline Constant & $\begin{array}{r}1.1165 \\
(0.3013)\end{array}$ & $* * *$ & $\begin{array}{l}7.63432 \\
(1.2790)\end{array}$ & $* * *$ & $\begin{array}{r}7.6633 \\
(1.3564)\end{array}$ & $* * *$ & $\begin{array}{r}1.1406 \\
(0.3351)\end{array}$ & $* * *$ & $\begin{array}{r}7.7027 \\
(1.3521)\end{array}$ & $* * *$ \\
\hline Supply Side Shock ${ }_{t-1}$ & & & & & & & $\begin{array}{r}-2.2823 \\
(4.2252)\end{array}$ & & $\begin{array}{l}-1.5243 \\
(6.8760)\end{array}$ & \\
\hline $\begin{array}{l}\text { Aggregate Demand } \\
\text { Shock }_{t-1}\end{array}$ & & & & & & & $\begin{array}{r}-2.2927 \\
(3.2401)\end{array}$ & & $\begin{array}{l}-4.6069 \\
(6.0706)\end{array}$ & \\
\hline $\begin{array}{l}\text { Oil Specific Demand } \\
\text { Shock }_{t-1}\end{array}$ & & & & & & & $\begin{array}{r}-1.1121 \\
(0.8132)\end{array}$ & & $\begin{array}{l}-3.1675 \\
(1.4150)\end{array}$ & $* *$ \\
\hline Oil Price Returns $s_{t-1}$ & $\begin{array}{l}-1.1722 \\
(0.7702)\end{array}$ & & & & $\begin{array}{r}-3.1380 \\
(1.3312)\end{array}$ & $* *$ & & & & \\
\hline Oil Price Volatilityt-1 & $\begin{array}{r}-2.3752 \\
(0.8993)\end{array}$ & $* * *$ & & & $\begin{array}{r}-0.0396 \\
(0.7966)\end{array}$ & & $\begin{array}{r}-2.5178 \\
(1.0043)\end{array}$ & $* *$ & $\begin{array}{l}-0.0106 \\
(0.8177)\end{array}$ & \\
\hline Default Spread $_{t-1}$ & & & $\begin{array}{r}-2.2169 \\
(0.4068)\end{array}$ & $* * *$ & $\begin{array}{r}-2.2910 \\
(0.4544)\end{array}$ & $* * *$ & & & $\begin{array}{l}-2.2893 \\
(0.4542)\end{array}$ & $* * *$ \\
\hline 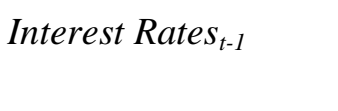 & & & $\begin{array}{l}-39.5687 \\
(11.1179)\end{array}$ & $* * *$ & $\begin{array}{l}-42.5199 \\
(11.9248)\end{array}$ & $* * *$ & & & $\begin{array}{r}-42.6276 \\
(12.0045)\end{array}$ & $* * *$ \\
\hline Inflation $_{t-1}$ & & & $\begin{array}{r}91.6441 \\
(24.3316)\end{array}$ & $* * *$ & $\begin{array}{r}97.9308 \\
(22.3027)\end{array}$ & $* * *$ & & & $\begin{array}{r}98.6602 \\
(22.2139)\end{array}$ & $* * *$ \\
\hline Dividend Yield ${ }_{t-1}$ & & & $\begin{array}{l}134.5263 \\
(28.4715)\end{array}$ & $* * *$ & $\begin{array}{l}139.9043 \\
(28.0132)\end{array}$ & $* * *$ & & & $\begin{array}{l}140.4472 \\
(27.7792)\end{array}$ & $* * *$ \\
\hline Unemployment $_{t-1}$ & & & $\begin{array}{r}-8.2814 \\
(5.0883)\end{array}$ & $*$ & $\begin{array}{r}-9.7905 \\
(5.5289)\end{array}$ & $*$ & & & $\begin{array}{r}-10.0118 \\
(5.7772)\end{array}$ & $*$ \\
\hline $\begin{array}{l}\text { Dow Jones Realised } \\
\text { Volatility }_{t-1}\end{array}$ & & & $\begin{array}{l}-24.3339 \\
(4.8904)\end{array}$ & $* * *$ & $\begin{array}{l}-23.7152 \\
(5.1172)\end{array}$ & $* * *$ & & & $\begin{array}{l}-23.7669 \\
(5.2051)\end{array}$ & $* * *$ \\
\hline McFadden $R^{2}$ & 0.0642 & & 0.7513 & & 0.7643 & & 0.0713 & & 0.7645 & \\
\hline
\end{tabular}

Note: In each specification, the dependent variable $P\left(d_{t}=1\right)$ is the probability of the Dow Jones volatility to be in state 1. $* * *, * *$ and $*$ denote statistical significance at the $1 \%, 5 \%$ and the $10 \%$ level, respectively. Huber (1967) and White (1980) robust standard errors are reported in parentheses. 
Table 6. Cumulative returns of the trading strategy based on the predicted market regimes according to i) the two-state regime switching model; equation (4), and ii) the probit regression model; equation (6), specification (5), for the returns and the volatility of Dow Jones index. The investment period runs from January, 1989 to December, 2011. For the VXD index, the investment period runs from October, 1997 to December, 2011.

\begin{tabular}{cccc}
\hline & \multicolumn{3}{c}{ Portfolio } \\
\hline Model & Dow Jones index & $\begin{array}{c}\text { Volatility of Dow } \\
\text { Jones index }\end{array}$ & VXD index \\
\hline $\begin{array}{c}\text { Two-state regime } \\
\text { switching model } \\
\text { Probit regression } \\
\text { model }\end{array}$ & $20.3 \%$ & $398 \%$ & $180 \%$ \\
\hline
\end{tabular}

Note: The regime switching model is $y_{i, t}=\mu_{i, j}+\varepsilon_{i, t, j}, \quad \varepsilon_{i, t, j} \sim \mathrm{N}\left(0, \sigma_{i, j}^{2}\right)$, where $y_{i, t}$ is the return or volatility of Dow Jones for $i=1,2$, respectively, $\mu_{i, j}$ and $\sigma_{i, j}$ are the conditional mean and the standard deviation for state $j=1,2$.

The Probit model is $P\left(\mathrm{~d}_{\mathrm{t}}=1\right)=\Phi\left(\beta_{i} \boldsymbol{O} \boldsymbol{I} \boldsymbol{L}_{t-1}, \gamma_{i} V O L O I L_{t-1}, \boldsymbol{\delta}_{i} \boldsymbol{X}_{t-1}\right)$ for $\boldsymbol{O I L}_{\boldsymbol{t}}=\left(S S_{t}, A D S_{t}, S D S_{t}\right)$ and $\boldsymbol{X}_{t}=D S_{t}, I N T_{t}, C P I_{t}, D Y_{t}, U N E M P_{t}, D O W_{t}$. 
Figure 1: Growth rates plots for the variables under investigation. The sample period runs from January, 1989 to December, 2011.

Panel A: Stock market variables

Dow Jones Returns

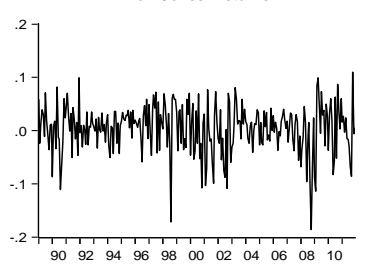

Dow Jones Realised Volatility

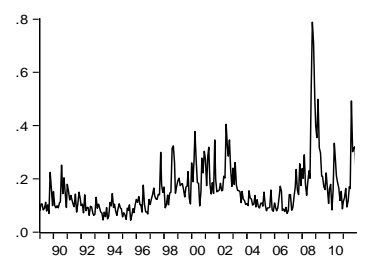

Dividend Yield

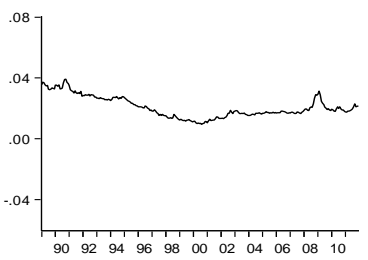

Panel B: Macroeconomic variables
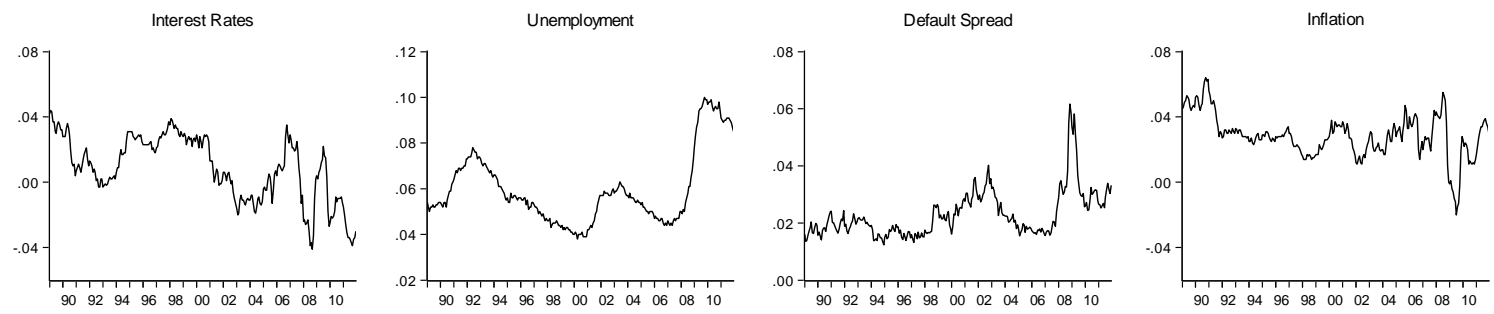

Panel C: Oil variables

Oil Production

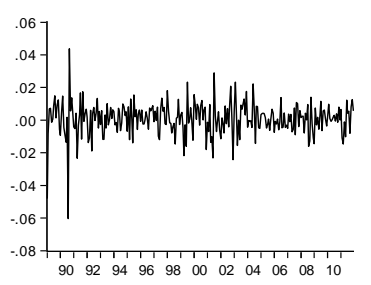

Oil Price Returns

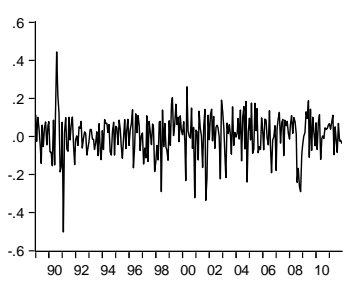

Global Economic Activity

Oil Price Volatility

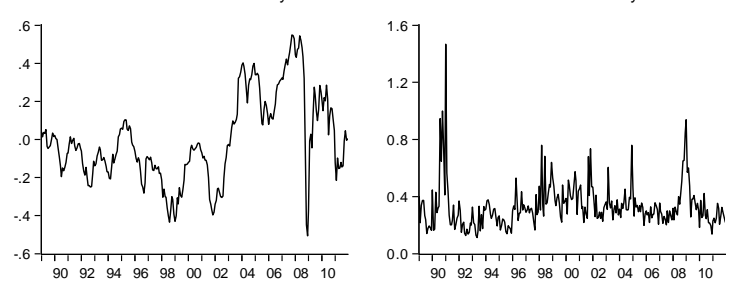


Figure 2: Smoothed probabilities of State 1 and of State 2 of Dow Jones returns and volatility. The sample period runs from January, 1989 to December, 2011.

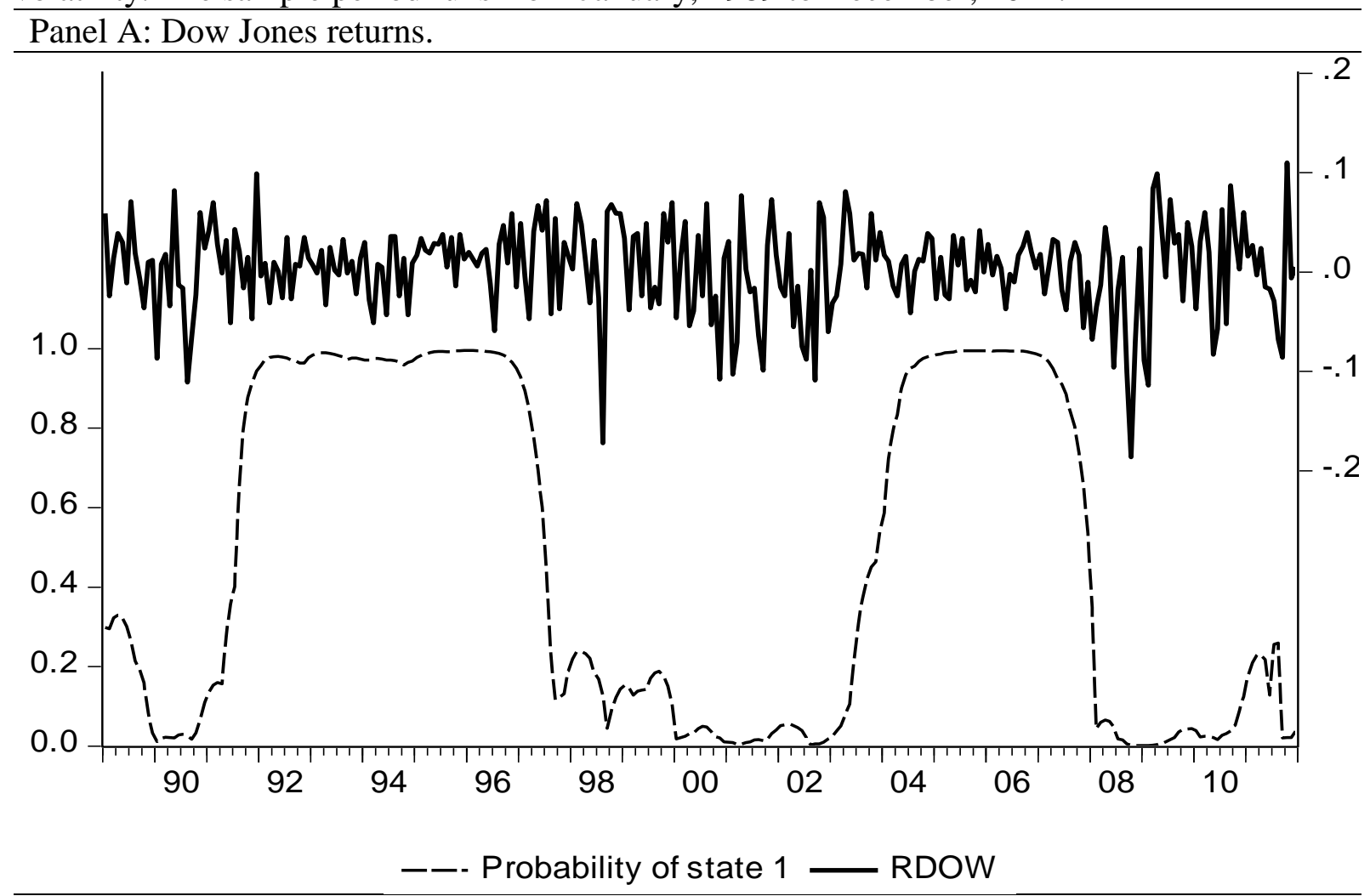

Panel B: Dow Jones volatility.

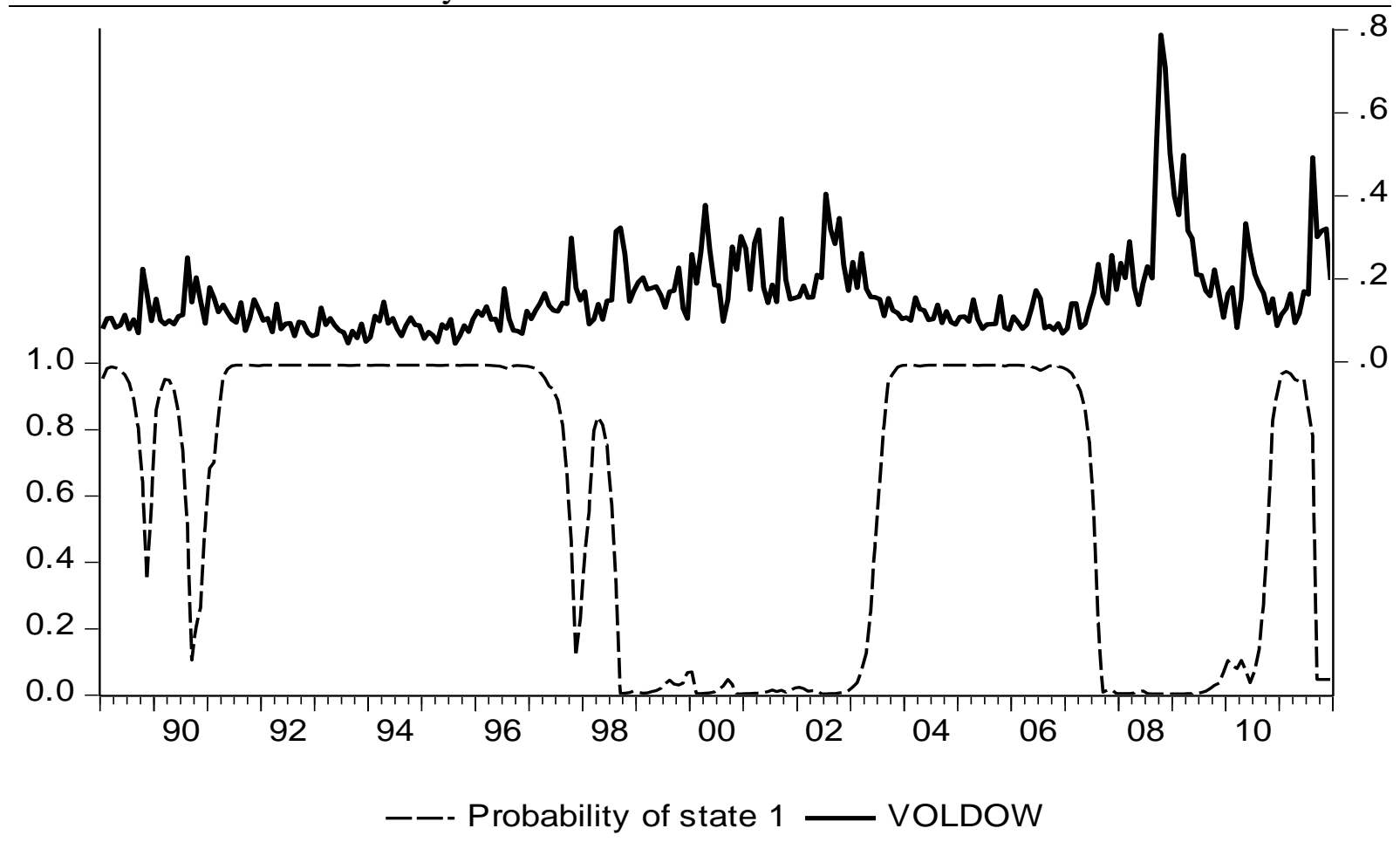

Note: For the Dow Jones returns, regime 1 is the high mean/low volatility, whereas regime 2 is the low mean/high volatility regime. For the Dow Jones volatility, regime 1 is the low mean/low volatility regime, whereas regime 2 is the high mean/high volatility regime. 
Figure 3: Cumulative returns of the trading strategies

Panel A: Cumulative returns of the trading strategy based on the predicted market regimes according to i) the two-state regime switching model; equation (4), and ii) the probit regression model; equation (6), specification (5), for the returns of Dow Jones index. The investment period runs from January, 1989 to December, 2011.

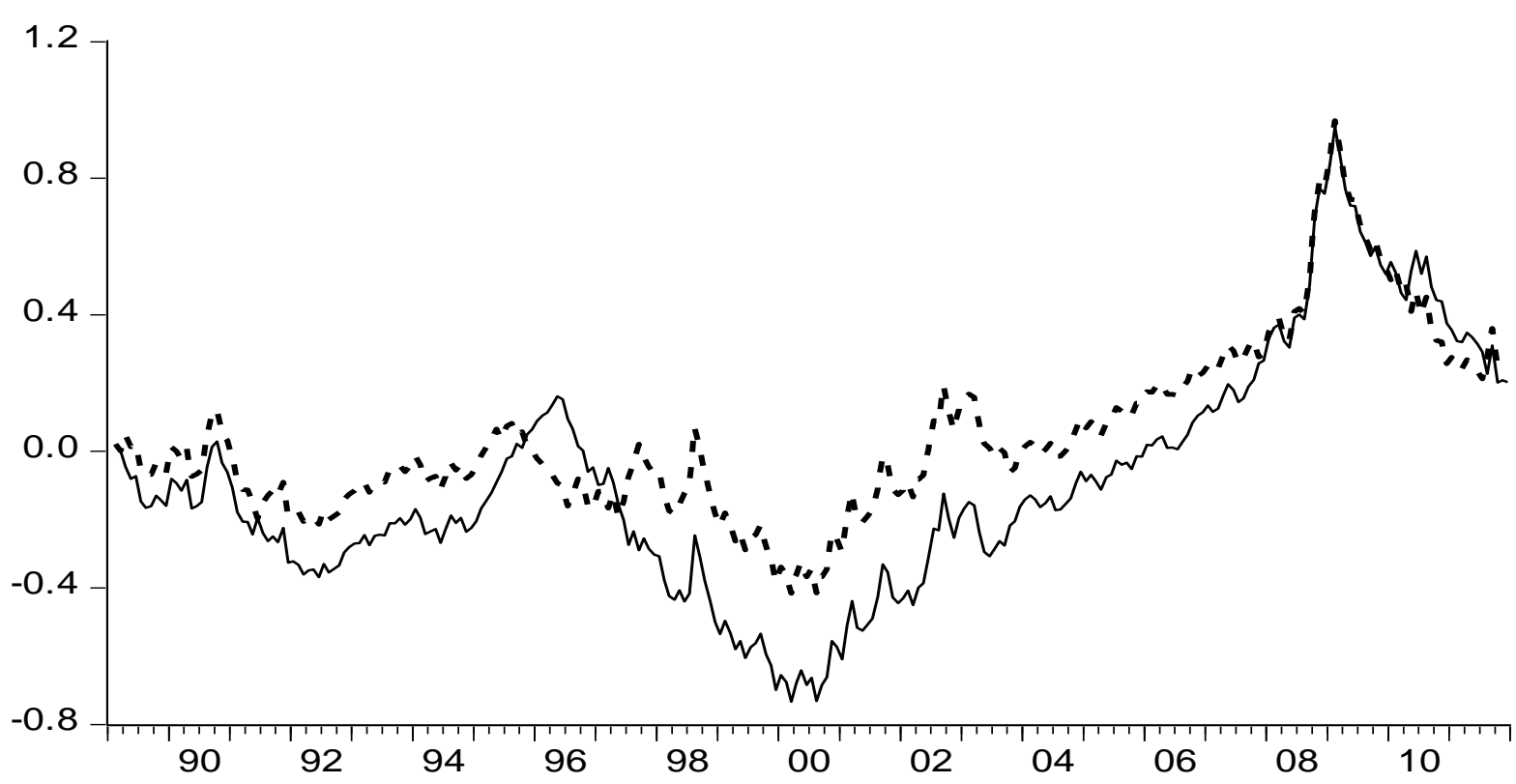

Regime switching model - - - Probit regression model

Panel B: Cumulative returns of the trading strategy based on the predicted market regimes according to i) the two-state regime switching model; equation (4), and ii) the probit regression model; equation (6), specification (5), for the volatility of Dow Jones index. The investment period runs from January, 1989 to December, 2011.

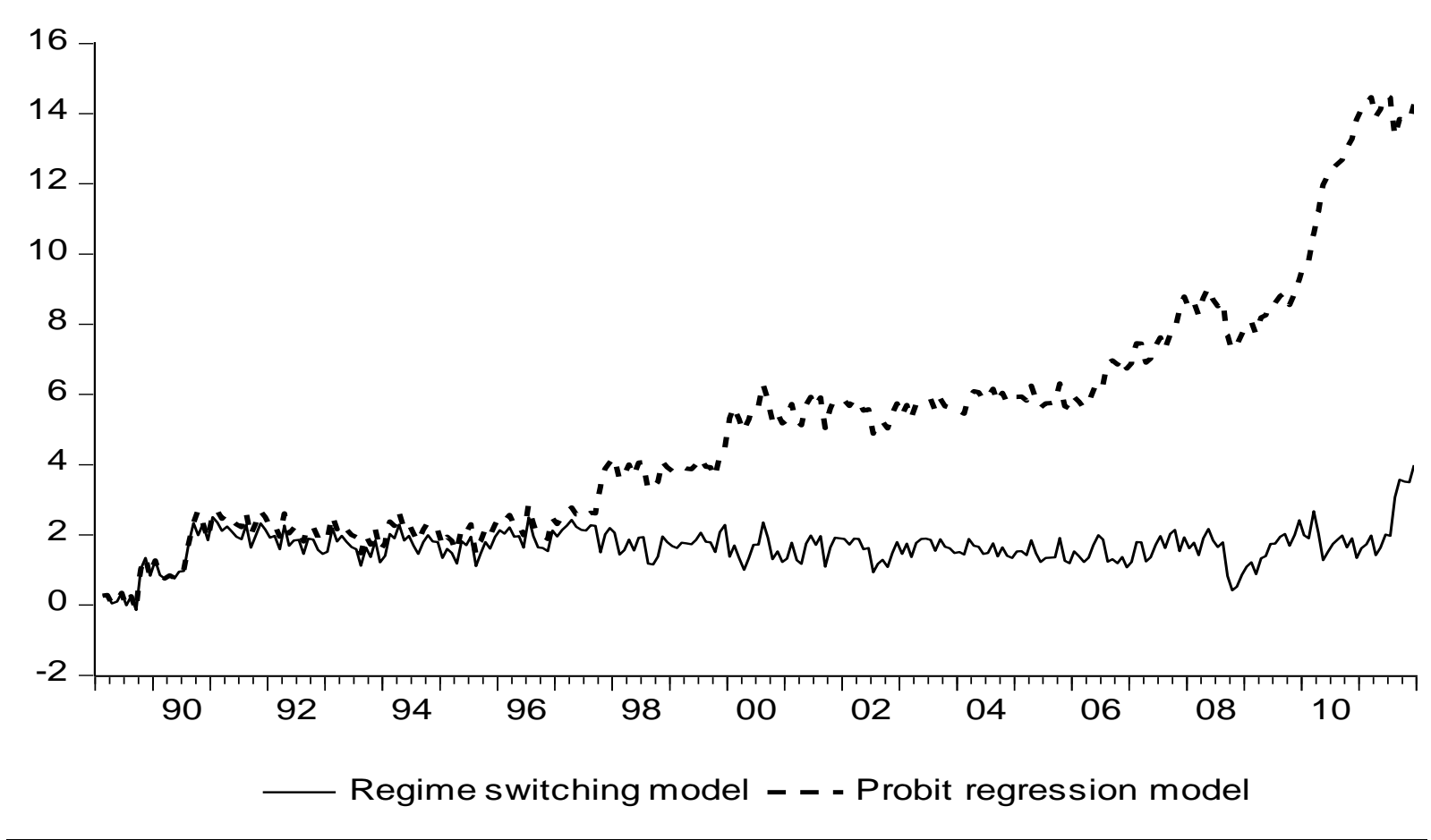

